\title{
Does zinc deficiency play a role in stunting among primary school children in NE Thailand?
}

\author{
Rosalind S. Gibson ${ }^{1}$, Mari Skar Manger ${ }^{1}$, Woravimol Krittaphol ${ }^{1}$, Tippawan Pongcharoen ${ }^{2}$, \\ Sueppong Gowachirapant ${ }^{2}$, Karl B. Bailey ${ }^{1}$ and Pattanee Winichagoon ${ }^{2}$ \\ ${ }^{1}$ Department of Human Nutrition, University of Otago, PO Box 56, Dunedin, New Zealand \\ ${ }^{2}$ Institute of Nutrition, Mahidol University at Salaya, Thailand \\ (Received 26 January 2006 - Revised 10 August 2006 - Accepted 29 August 2006)
}

\begin{abstract}
Stunting in school-age years may result in a decrease in adult size, and thus reduced work capacity and adverse reproductive outcomes. We have compared the mean intakes of energy, protein and selected growth-limiting nutrients in fifty-eight stunted children and 172 non-stunted controls drawn from 567 children aged 6-13 years attending ten rural schools in NE Thailand. Control children were selected randomly after stratifying children by age in each school. Dietary data were calculated from 24-h recalls using nutrient values from Thai food composition data and chemical analysis. Inter-relationships between stunting and sociodemographic, anthropometric and biochemical variables were also examined. Biochemical variables investigated were serum albumin, zinc, ferritin, transferrin receptor and retinol, and iodine in casual urine samples. Significantly more males than females were stunted (males, $n 38,65.5 \% v$. females, $n 20,34.5 \%$; $P=0.025$ ). Stunted males had lower mean intakes of energy, protein, calcium, phosphorus and zinc, and a lower mean (95\% CI) serum zinc $(9.19(8.53,9.84) v .9 .70(8.53,9.29) \mu$ mol/l) than non-stunted males; no other biochemical differences were noted. Stunted males also had a lower mean arm muscle area $(P=0 \cdot 015)$, after adjusting for age, than nonstunted males. In conclusion, the lower dietary intakes of the stunted males compared to their non-stunted counterparts may be associated with anorexia and hypogeusia induced by zinc deficiency. Hence, zinc deficiency may be a factor limiting linear growth, especially among boys in NE Thailand, but more research is needed to establish whether other factors also play a role.
\end{abstract}

Dietary intakes: Dietary quality: Serum zinc: Anthropometry

Stunting is defined by the WHO as the gaining of insufficient height relative to age (World Health Organization, 1995). It is an indicator of chronic undernutrition, and is the result of extended periods of inadequate food intake, poor dietary quality, increased morbidity, or a combination of these factors (Gopalan, 1988). The processes that lead to stunting can occur both pre- and post-natally (Rivera \& Ruel, 1997). The prevalence of stunting is generally highest during the second and third years of life (World Health Organization, 1986), but it often persists into school-age years. Understanding stunting among this older age-group is important because, if still untreated, stunting results in a reduction in adult size. This, in turn, has been associated with reduced work capacity (Spurr, 1988) and, in women, adverse reproductive outcomes (Adair \& Guilkey, 1997).

The northeast region of Thailand is the poorest in the country. Rainfall is low and erratic, so that the region is very susceptible to drought and hence poor rice yields. The capita income and education level in this region are among the lowest in the country, whereas the family size is generally larger compared to the national average (5.7 v. 4.0 members; Ministry of Public Health, 1995). A large family size has been shown to be a risk factor for malnutrition in young children in several studies (e.g. Pelto et al. 1991). Hence, it is not surprising that in NE Thailand, low intakes of energy and several growth-limiting micronutrients (e.g. calcium, phosphorus, iron, vitamin A and zinc) have been reported among preschool (Chusilp et al. 1992; Ministry of Public Health, 1995) and school-aged children (Bloem et al. 1989; Egger et al. 1991; Udomkesmalee et al. 1992). Deficits in some of these micronutrients in school-aged children have been associated with reduced linear growth, as well as impaired immune competence, cognition and school performance (Soemantri et al. 1985; Kramer et al. 1993; Sandstead et al. 1998; Van Stuijvenberg et al. 1999). If these micronutrient deficits persist, the likelihood of catch-up growth is diminished.

Of the growth-limiting micronutrients, zinc is likely to be most limiting in developing countries in which children consume plant-based diets with a low content of total or absorbable zinc (Gibson, 1993; Yeudall et al. 2005). In NE Thailand, glutinous rice (Oryza glutionosa) or noodles prepared from rice flour often contribute as much as $70 \%$ of the total energy of the diets of children (Winichagoon, 2002). In much of this area, the soil is low in zinc (Alloway, 2004), and as a result, rice grown locally has a low zinc content (Umar Khan et al. 2002; Welch \&

Abbreviations: WHO, World Health Organization; RCT, randomized controlled trial; HAZ, height-for-age z-score; NCHS, National Centre for Health Statistics; CRP, C-reactive protein; WAZ, weight-for-age z-score; WHZ, weight-for-height z-score; HOH, Head of household; BMI, Body mass index; AMA, arm muscle area; MJ, megajoules; FAO/WHO/UNU, Food \& Agriculture Organization/World Health Organization/United Nations University.

* Corresponding author: Rosalind S. Gibson, fax +6 3479 7958, email Rosalind.Gibson@Stonebow.Otago.AC.NZ 
Graham, 2004). Hence, NE Thai children may be especially at risk to low intakes of total dietary zinc (Udomkesmalee et al. 1992; Krittaphol et al. in press).

In the present study, we have compared the intakes of energy, protein and selected growth-limiting micronutrients in stunted and non-stunted primary school children living in rural NE Thailand. Inter-relationships between stunting and sociodemographic, anthropometric and biochemical variables were also examined. Biochemical zinc status was based on serum zinc, iron status on serum ferritin and transferrin receptor, vitamin A status on serum retinol, iodine status on iodine in casual urine samples, and protein status on serum albumin concentrations.

\section{Subjects and methods}

\section{Subjects}

The present study was undertaken in Ubon Ratchathani province, NE Thailand. The subjects were a subsample drawn from primary school children (284 males, 285 females) who were participating in the baseline data collection of a randomized controlled trial (RCT) conducted between June 2002 and March 2003. All the children for the RCT were attending ten primary schools situated in poor rural subdistricts of the Trakarn Phutphon district. For the RCT, children were stratified in each school into four strata: females grades 1-3; males grades 1-3; females grades 4-6; males grades 4-6. Fifteen children were selected randomly from each stratum, although in strata with less than fifteen children, all children were selected. To minimize correlation between participants, only one child per family was selected.

For the subsample of children reported in the present study, a representative sample of stunted children ( $n$ 58) from the larger sample ( $n$ 567) were included in the subsample and compared with a non-stunted control group consisting of up to five randomly selected non-stunted children from each stratum within each school. This yielded a total sample size of fifty-eight stunted and 172 non-stunted children. This sample size permits a difference in the mean zinc intakes of $0.8 \mathrm{mgZn} / \mathrm{d}$ to be detected between the stunted and nonstunted children, based on a standard deviation in zinc intake of $1.8 \mathrm{mg} / \mathrm{d}$ (Kritttaphol, personal communication) assuming $\alpha$ (two-tailed) $=0.05$ and $\beta=0.10$ (Hulley \& Cummings, 1988). Stunted children were defined as those with height-for-age Z-scores (HAZ) $<-2$ calculated from the 1977 National Center for Health Statistics (NCHS) growth reference data using Epi-Info version 6.0 (USD Inc. Stone Mountain, GA, USA).

The Human Ethics Committees from the University of Otago (New Zealand) and Mahidol University (Thailand) approved the study protocol. Permission was also obtained from local school boards, Thai health workers, and the parents or guardians of the children, as noted previously (Thurlow et al. 2005).

\section{Method}

Details of the methods used to collect information on the sociodemographic, health, anthropometric and biochemical micronutrient status of the children who participated in the RCT at baseline have been reported elsewhere (Thurlow et al. 2005, 2006). Onset of infection was assessed by measurement of serum C-reactive protein (CRP), as described previously (Thurlow et al. 2005). A CRP value of $\geq 10 \mathrm{mg} / \mathrm{l}$ was used to indicate the presence of infection or inflammation. Children with elevated serum CRP were excluded from the statistical analyses.

We collected dietary data from the stunted and non-stunted control group using the interactive 24-h recall method, validated earlier (Ferguson et al. 1989, 1995). Details of this method are given in Gibson \& Ferguson (1999). Children were randomly allocated into either weekend or weekday groups within each stratum to ensure that both weekday and weekend days were represented in the final sample of recall days. Parents were instructed not to change the dietary patterns of their children on the recall day. Trained research assistants interviewed the children at school, along with their primary caregiver. If a child could not attend school on the day of the scheduled interview, the interviewer visited the child at home. To assist in the estimation of portion sizes, measurement aids such as graduated measuring cups and spoons, household spoons, tape measures, plastic food models of common foods, portions of cooked rice, and weighing scales (Soehnle, CMS Weighing Equipment, London, UK) were used (Gibson, 2005).

Average daily intakes and major food sources of energy, protein, selected growth-limiting micronutrients and phytate were calculated from the $24-\mathrm{h}$ recalls. Indicators of dietary quality were also determined based on the proportion of energy from animal protein (as a percentage), nutrient intakes per MJ (i.e. nutrient densities), and intakes of animal protein, haem iron, and phytate:iron, phytate:calcium and phytate:zinc molar ratios. Intakes were calculated using nutrient and phytate values from food composition databases, with the exception of ten food items frequently consumed by the children, including steamed glutinous rice (Oryza glutinosa). For these ten foods, values for calcium, iron, zinc and phytate were obtained by chemical analyses, as described by Krittaphol et al. (in press). Most of the food composition values used were taken from the Thai Food Composition Database for the INMUCAL program (Institute of Nutrition, Mahidol University, 2002). However, for any food item with missing nutrient values, alternative food composition databases were used (Bunch \& Murphy, 1994; Siong et al. 1997; Puwastien et al. 2000; United States Department of Agriculture, 2003).

Adjustments were made to the food composition values obtained by chemical analyses or from the alternative databases to take into account any discrepancies in their moisture content compared to that stated in the INMUCAL database. If a food could not be found in any of the additional sources, values for a similar Thai food were used based on advice from a Thai nutritionist (T.P.). When data were not available in the cooked form, nutrient values were derived from dried or raw foods using adjustments for changes in yield and nutrient retention, where appropriate, as described by Gibson \& Ferguson (1999). The yield factors used for cooked NE Thai foods were compiled by Banjong et al. (2001).

\section{Statistical analysis}

Statistical analyses were carried out using SPSS version 12 (USD Inc., Stone Mountain, GA, USA). All continuous 
variables were examined for normality using the Kolmogorov-Smirnov test. Dietary intake results are expressed as median (interquartile range) for consistency because of nonnormal distributions of some nutrients. The binomial test, with a two-tailed significance based on the Z-approximation, was used to test for sex differences among the stunted group; Fisher's exact test was used for examining sex differences among children with low serum zinc concentrations indicative of zinc deficiency (Hotz \& Brown, 2004).

Analysis of covariance (ANCOVA) was used to calculate the means of the stunted and non-stunted groups for each sex while simultaneously adjusting for age. Two sets of variables were examined: first, intakes of energy, protein, animal protein, calcium, phosphorus, zinc and iron; second, biochemical indices of protein, iron, vitamin A, iodine and zinc status; each dietary and biochemical variable was tested separately. Sex and stunting [ $<$ or $\geq \mathrm{HAZ}-2 \mathrm{SD}$ ] were treated as independent classificatory variables and age as a covariate. In addition, the two-way interaction effects for each model were assessed for significance. All models conformed to the assumptions of the General Linear Model. A $P$ value $<0.05$ was taken to indicate statistical significance.

\section{Results}

Of the 230 children selected for this study, 226 children (124 males, 102 females) participated in the 24-h recalls, giving a response rate of $98 \%$. All the children who participated were of Thai ethnicity.

\section{Socio-economic and anthropometric status indicators}

The results shown in Table 1 indicate that the socio-economic status of the households of stunted and non-stunted children was comparable. More than $80 \%$ of both groups of children came from male-headed households in which the head of household or the primary caregiver had received only primary-school education. The major occupation for more than $90 \%$ of the households in both groups was farming, primarily rice-growing. The annual income of nearly $60 \%$ of the households was less than 30000 Baht, or approximately US\$750.00 per year. The median family size was five in both groups.

Table 1. Sociodemographic characteristics of non-stunted ( $n$ 169) and stunted $(n 58)$ children

\begin{tabular}{|c|c|c|c|c|}
\hline & \multicolumn{2}{|c|}{ Non-stunted } & \multicolumn{2}{|c|}{ Stunted } \\
\hline & $n$ & $\%$ & $n$ & $\%$ \\
\hline \multicolumn{5}{|l|}{ Head of household $(\mathrm{HOH})$} \\
\hline Male & 143 & $84 \cdot 6$ & 52 & 89.7 \\
\hline \multicolumn{5}{|l|}{ Education of $\mathrm{HOH}$} \\
\hline Primary school & 146 & $86 \cdot 4$ & 48 & $82 \cdot 8$ \\
\hline \multicolumn{5}{|l|}{ Occupation of $\mathrm{HOH}$} \\
\hline Agriculture & 152 & 89.9 & 55 & 94.8 \\
\hline \multicolumn{5}{|l|}{ Education of caregiver/mother } \\
\hline Primary school & 151 & $89 \cdot 3$ & 49 & $84 \cdot 5$ \\
\hline \multicolumn{5}{|l|}{ Estimated yearly income } \\
\hline$\leq 30000$ (baht) & 98 & $58 \cdot 0$ & 33 & $56 \cdot 9$ \\
\hline \multicolumn{5}{|l|}{ Land ownership } \\
\hline Own family land & 141 & 83.4 & 53 & 91.4 \\
\hline
\end{tabular}

Of the stunted children ( $n$ 58), a significantly higher proportion $(65.5 \%)$ were male (Table 2$)$. The mean ages of the two groups studied were similar and regression analysis (data not shown) suggests that the degree of stunting as indicated by the HAZ is independent of age. As might be expected, the mean weight-for-age Z-score (WAZ) for the stunted children was also lower than for the non-stunted children. The mean weight-for-height Z-score (WHZ) and the mean BMI for the stunted children were significantly lower than for the non-stunted children, as were other related variables including mid-arm circumference, arm muscle area, arm fat area, triceps skinfold and subscapular skinfold. There were no significant sex differences for any of the anthropometric variables except for arm muscle area (AMA; Table 2); males had a significantly higher AMA than females (2001 v. $1869 \mathrm{~mm}^{2} ; P=0 \cdot 015$ ).

\section{Intakes of energy, nutrients and dietary quality indicators}

The median daily intakes (first and third quartiles) for energy, selected growth-limiting nutrients, dietary fibre and phytate for the non-stunted and stunted children are shown in Table 3. For both groups, median intakes of energy, and most of the nutrients examined, with the exception of protein, are low when compared to the Thai Recommended Daily Dietary Allowances (Ministry of Public Health, 1989).

Median intakes of fat and total protein (g/day) and phosphorus were significantly lower $(P<0.05)$ in the stunted group, with a tendency for lower intakes of energy $(P=0.062)$ and zinc $(P=0 \cdot 086)$. By contrast, intakes of the other micronutrients were not significantly different in the stunted compared with the non-stunted children.

Dietary quality indicators are shown in Table 4. Stunted children had significantly lower median daily intakes of both energy and protein from animal sources, predominantly flesh foods $(P<0 \cdot 01)$. However, other indicators of dietary quality, including haem iron, and the $[\mathrm{Phy}]:[\mathrm{Ca}],[\mathrm{Phy}]:[\mathrm{Fe}]$ and [Phy]:[Zn] molar ratios, were similar in the two groups.

ANCOVA (Table 5) provides further insight on the dietary data presented in Tables 3 and 4. Each of the dietary intake variables shown in Table 5 was analysed separately with sex and stunting as categorical independent variables and age as a covariate. The results reveal that for the intakes of energy, protein and phosphorus, there is a significant interaction between sex and stunting, sometimes with age as a significant covariate; the intakes of the male stunted group are anomalously low. The same pattern can be observed for the zinc intakes, although in this case the interaction term is not significant $(P=0.067)$. For other nutrients (not shown) the pattern is less obvious, but even for iron, where the significance of the interaction is 0.581 , the stunted males have a lower intake than the non-stunted males (Table 5), emphasizing the expected coherence of the dietary intake data.

\section{Biochemical indices}

Of the biochemical indices treated as dependent variables and shown in Table 6, only serum zinc was significantly influenced by stunting, with a significant two-way interaction between stunting and sex; stunted males had a significantly lower mean serum zinc than either stunted females or non-stunted 
Table 2. Age, proportion of males, and the mean ( $95 \% \mathrm{Cl})$ of selected anthropometric variables for non-stunted $(n 169)$ and stunted $(n 58)$ children

\begin{tabular}{|c|c|c|c|c|c|}
\hline & \multicolumn{2}{|c|}{ Non-stunted } & \multicolumn{2}{|c|}{ Stunted } & \multirow[b]{2}{*}{$P^{*}$} \\
\hline & Mean & $95 \% \mathrm{Cl}$ & Mean & $95 \% \mathrm{Cl}$ & \\
\hline Males $n$ & 86 & & 38 & & \\
\hline$\%$ & $50 \cdot 9+$ & & 65.5 & & $0.025 \ddagger$ \\
\hline Age (months) & $110 \cdot 7$ & $107 \cdot 6,113 \cdot 7$ & $114 \cdot 7$ & $109 \cdot 5,119 \cdot 9$ & $0.174 \S$ \\
\hline $\mathrm{HAZ}$ & -0.98 & $-1.07,-0.88$ & -2.44 & $-2 \cdot 60,-2 \cdot 27$ & \\
\hline WAZ & $-1 \cdot 16$ & $-1 \cdot 27,-1.05$ & $-2 \cdot 17$ & $-2.41,-2.03$ & \\
\hline WHZ ( $n$ 147) & -0.74 & $-0.89,-0.60$ & -1.03 & $-1.26,-0.80$ & 0.038 \\
\hline BMI & $15 \cdot 1$ & $14 \cdot 8,15 \cdot 3$ & $14 \cdot 1$ & $13 \cdot 7,14 \cdot 6$ & $<0.001$ \\
\hline Mid-arm circumference $(\mathrm{cm})$ & 18.4 & $18 \cdot 1,18 \cdot 6$ & $16 \cdot 8$ & $16 \cdot 3,17 \cdot 2$ & $<0.001$ \\
\hline Arm muscle area $\left(\mathrm{mm}^{2}\right)$ & 2086 & 2035,2137 & 1780 & 1691,1869 & $<0.001 \|$ \\
\hline Arm fat area $\left(\mathrm{mm}^{2}\right)$ & 640 & 593,686 & 467 & 387,548 & $<0.001$ \\
\hline Triceps skinfold (mm) & $7 \cdot 2$ & $6 \cdot 8,7 \cdot 6$ & 5.9 & $5 \cdot 2,6 \cdot 6$ & 0.001 \\
\hline Subscapular skinfold (mm) & 5.5 & $5 \cdot 2,5 \cdot 8$ & 4.4 & $3.9,4.9$ & $<0.001$ \\
\hline
\end{tabular}

HAZ, height-for-age Z-score; WAZ, weight-for-age Z-score; WHZ, weight-for-height Z-score.

* Significance, except where indicated, from univariate analysis of covariance (ANCOVA), of the difference between the non-stunted and stunted children, with sex and stunting treated as categorical variables and age as a covariate. The interaction term sex $\times$ stunting was not significant in any of the ANCOVA models. Means for each model were evaluated at age 111.7 months.

†The stratified sampling scheme adopted ensured that the two sexes were approximately equally represented in the non-stunted group.

†From the binomial test on the stunted group, two-tailed significance based on the Z-approximation.

$\S$ Significance for non-paired $t$ test.

\| Significance for $\operatorname{sex}=0.015$.

males and females. The prevalence of low serum zinc concentrations indicative of zinc deficiency was higher among the male children $(69 \%, n$ 72) than the female children $(55 \%, n$ 47; $P=0 \cdot 050$, Fisher's exact test).

\section{Discussion}

The present results indicate that, of the rural NE Thai children in the present study, it was the stunted males who had the lowest mean serum zinc concentration (Table 6). The prevalence of low serum zinc concentrations, indicative of zinc deficiency, was also higher among the male children. Male children also formed a disproportionately high percentage of the stunted group; that is, nearly two-thirds of the group (Table 2). Several other studies have reported that males are more vulnerable to zinc deficiency than females (Smit-Vanderkooy \& Gibson,
1987; Gibson et al. 1991; Cavan et al. 1993; Parnell et al. 2003), presumably because of a higher requirement for zinc. This may be partly due to a higher growth rate and greater proportion of muscle per kilogram body weight as muscle contains a higher content of zinc than fat (Hotz \& Brown, 2004). Indeed, in several zinc supplementation trials, the zinc-supplemented males have shown a greater response in linear growth than their female counterparts (Walravens \& Hambidge, 1976; Walravens et al. 1983; Hambidge et al. 1985; Castillo-Duran et al. 1994; Ruz et al. 1997).

The onset of the pubertal growth spurt was probably not a significant confounder in the present study. Menarche had not commenced in any of the girls studied, and peak height velocity occurs later for boys than girls. Hence, it is likely that at the time of the present cross-sectional study, most of the boys had not experienced their pubescent growth spurt and associated

Table 3. Median daily intakes (first and third quartiles) for energy, selected growth-limiting nutrients, phytate and dietary fibre for the non-stunted ( $n$ $169)$ and stunted $(n 58)$ children

\begin{tabular}{|c|c|c|c|c|c|c|}
\hline & \multicolumn{3}{|c|}{ Non-stunted } & \multicolumn{3}{|c|}{ Stunted } \\
\hline & Median & First quartile & Third quartile & Median & First quartile & Third quartile \\
\hline Energy (MJ) & 5.25 & 4.37 & 6.63 & 4.90 & 3.95 & 5.95 \\
\hline Carbohydrate (g) & 223 & 178 & 274 & 214 & 164 & 270 \\
\hline Fat $(\mathrm{g})$ & 23.1 & $15 \cdot 0$ & 30.5 & $19 \cdot 6$ & $15 \cdot 0$ & $25 \cdot 1$ \\
\hline Protein (g) & $40 \cdot 2$ & 32.9 & $49 \cdot 2$ & 37.8 & $27 \cdot 1$ & $43 \cdot 8$ \\
\hline Calcium (mg) & 224 & 105 & 304 & 222 & 101 & 278 \\
\hline Phosphorus (mg) & 390 & 279 & 485 & 332 & 273 & 398 \\
\hline Iron (mg) & $5 \cdot 2$ & 4.0 & $7 \cdot 2$ & 4.9 & 3.6 & $7 \cdot 1$ \\
\hline Zinc (mg) & 4.5 & 3.5 & 5.5 & 4.3 & $3 \cdot 1$ & $5 \cdot 1$ \\
\hline Vitamin A (RAE) & 206 & 105 & 301 & 183 & 95 & 292 \\
\hline Vitamin $B_{1}(\mathrm{mg})$ & 0.39 & 0.29 & 0.57 & 0.38 & 0.25 & 0.60 \\
\hline Vitamin $B_{2}(\mathrm{mg})$ & 0.94 & 0.72 & 1.20 & 0.88 & 0.66 & 1.08 \\
\hline Vitamin C (mg) & $22 \cdot 2$ & $6 \cdot 5$ & 44.5 & 21.4 & 4.6 & 57.5 \\
\hline $\operatorname{Niacin}(\mathrm{mg})$ & $7 \cdot 21$ & $5 \cdot 50$ & 9.94 & 6.60 & 4.89 & 9.02 \\
\hline Dietary fibre (g) & 3.5 & 1.9 & $5 \cdot 3$ & $3 \cdot 2$ & $2 \cdot 0$ & $6 \cdot 0$ \\
\hline Phytate $(\mathrm{mg})$ & 80 & 58 & 113 & 74 & 52 & 105 \\
\hline
\end{tabular}

RAE, retinol activity equivalents. 
Table 4. Median indicators (first and third quartiles) of dietary quality for the non-stunted ( $n$ 169) and stunted ( $n$ 58) children

\begin{tabular}{|c|c|c|c|c|c|c|}
\hline & \multicolumn{3}{|c|}{ Non-stunted } & \multicolumn{3}{|c|}{ Stunted } \\
\hline & Median & First quartile & Third quartile & Median & First quartile & Third quartile \\
\hline Energy from animal protein (MJ) & 0.36 & 0.25 & 0.51 & 0.31 & $0 \cdot 23$ & 0.38 \\
\hline Protein density (mg/MJ) & $7 \cdot 6$ & $6 \cdot 8$ & 8.6 & $7 \cdot 4$ & $6 \cdot 7$ & $8 \cdot 1$ \\
\hline Animal protein $(\mathrm{g})$ & $21 \cdot 3$ & 14.5 & $30 \cdot 0$ & $18 \cdot 0$ & $13 \cdot 6$ & $22 \cdot 1$ \\
\hline Iron from animal products (mg) & 2.35 & 1.47 & 3.60 & 2.04 & 1.43 & 3.93 \\
\hline Iron from meat, poultry, fish (mg) & 1.44 & 0.78 & $2 \cdot 48$ & $1 \cdot 28$ & 0.79 & $2 \cdot 11$ \\
\hline Iron from vegetables (mg) & $2 \cdot 31$ & $1 \cdot 77$ & 3.55 & $2 \cdot 32$ & 1.62 & $3 \cdot 31$ \\
\hline Haem iron $(\mathrm{mg})$ & 0.94 & 0.59 & 1.44 & 0.82 & 0.57 & 1.57 \\
\hline$[\mathrm{Phy}]:[\mathrm{Ca}]$ molar ratio & 0.02 & 0.01 & 0.05 & 0.03 & 0.01 & 0.04 \\
\hline [Phy]:[Fe] molar ratio & $1 \cdot 31$ & 0.96 & $1 \cdot 84$ & $1 \cdot 22$ & 0.82 & $1 \cdot 70$ \\
\hline$[\mathrm{Phy}]:[\mathrm{Zn}]$ molar ratio & $1 \cdot 70$ & $1 \cdot 34$ & $2 \cdot 36$ & $1 \cdot 71$ & 1.32 & 2.25 \\
\hline Calcium density (mg/MJ) & $36 \cdot 5$ & $18 \cdot 7$ & $58 \cdot 5$ & $38 \cdot 1$ & $19 \cdot 3$ & $68 \cdot 3$ \\
\hline Phosphorous density (mg/MJ) & 73.9 & 53.9 & $91 \cdot 7$ & 68.9 & 56.9 & 83.4 \\
\hline Iron density (mg/MJ) & 0.99 & 0.79 & $1 \cdot 20$ & 0.97 & 0.80 & 1.26 \\
\hline Zinc density (mg/MJ) & 0.82 & 0.75 & 0.91 & 0.83 & 0.76 & 0.92 \\
\hline Energy per kg body weight (MJ/kg) & $0 \cdot 21$ & 0.17 & 0.27 & 0.24 & 0.19 & 0.28 \\
\hline Protein per $\mathrm{kg}$ body weight $(\mathrm{g} / \mathrm{kg})$ & 1.68 & $1 \cdot 26$ & $2 \cdot 17$ & $1 \cdot 78$ & 1.45 & 2.05 \\
\hline
\end{tabular}

increases in muscle mass (World Health Organization, 1995), especially as zinc deficiency delays secondary sexual maturation in boys (Hotz \& Brown, 2004). The significant interaction observed in the covariance model between stunting and sex was independent of age (Table 5), suggesting that the relationships observed applied across the age range studied.

Impaired linear growth is a prominent feature of zinc deficiency among children in both developed and developing countries (Aggett, 1995; Hambidge, 2000; Brown et al. 2002). The present results demonstrate a significant and positive relationship between stunting among the male children of the study and serum zinc concentrations (Table 6). By contrast, no relationships were found between stunting among the male children and other biochemical indices of growth-limiting nutrients, such as serum albumin, $\log$ serum ferritin, serum transferrin receptor, serum retinol or urinary iodine concentrations (Table 6), suggesting that neither protein, iron, vitamin A nor iodine status was associated with the higher prevalence of stunting among the males, at the time period of the present study.
The existence of zinc deficiency among the NE Thai children was confirmed by a significant increase in serum zinc concentration among those children who participated in the RCT and received a school lunch containing a seasoning powder fortified with zinc (and vitamin A, iron and iodine) for 31 weeks, compared to those consuming an unfortified lunch (Winichagoon et al. 2006).

We also observed a striking feature of the dietary intakes of the male stunted children; their intakes of energy, protein and phosphorus were lower compared to the female stunted and the non-stunted children of both sexes, whereas their intakes of calcium and zinc were lower than those of their non-stunted counterparts (Table 5). It is possible that the low biochemical zinc status of these stunted males was responsible, at least in part, for the low dietary intakes. In some studies, poor appetite (Krebs et al. 1984; Umeta et al. 2002) and impaired taste acuity (Hambidge et al. 1972; Buzina et al. 1983; Gibson et al. 1989; Cavan et al. 1993) have been associated with mild zinc deficiency in children, which together, if present, could lead to

Table 5. Analysis of covariance (ANCOVA) of energy and other nutrient intakes with sex and stunting treated as categorical variables and age as a covariate for the non-stunted ( $n$ 169) and stunted $(n 58)$ children

\begin{tabular}{|c|c|c|c|c|c|c|c|}
\hline \multirow[b]{2}{*}{ Dependent variable } & \multirow[b]{2}{*}{ Sex } & \multicolumn{2}{|c|}{ Non-stunted } & \multicolumn{2}{|c|}{ Stunted } & \multicolumn{2}{|c|}{$P$} \\
\hline & & Mean & $95 \% \mathrm{Cl}$ & Mean & $95 \% \mathrm{Cl}$ & Sex $\times$ stunting $^{a}$ & $\mathrm{Age}^{\mathrm{b}}$ \\
\hline \multirow[t]{2}{*}{ Energy (MJ) } & $\mathrm{F}$ & 5.05 & $4 \cdot 71,5 \cdot 39$ & $5 \cdot 04$ & $4 \cdot 35,5 \cdot 73$ & 0.027 & 0.001 \\
\hline & $M$ & 6.01 & $5 \cdot 67,6 \cdot 34$ & 4.88 & $4 \cdot 38,5 \cdot 39$ & & \\
\hline \multirow[t]{2}{*}{ Protein (g) } & $\mathrm{F}$ & 38.8 & $35 \cdot 9,41 \cdot 7$ & 37.8 & $31.9,43 \cdot 8$ & 0.042 & 0.024 \\
\hline & M & $45 \cdot 8$ & $42 \cdot 9,48 \cdot 6$ & $36 \cdot 1$ & $31 \cdot 7,40 \cdot 4$ & & \\
\hline \multirow[t]{2}{*}{ Animal protein (g) } & $\mathrm{F}$ & 21.4 & $19 \cdot 2,23 \cdot 7$ & $19 \cdot 7$ & $15 \cdot 2,24 \cdot 3$ & 0.190 & 0.660 \\
\hline & $\mathrm{M}$ & $24 \cdot 2$ & $22 \cdot 0,26 \cdot 4$ & $18 \cdot 1$ & $14 \cdot 8,21 \cdot 4$ & & \\
\hline \multirow[t]{2}{*}{ Calcium (mg) } & $\mathrm{F}$ & 206 & 169,244 & 239 & 162,316 & 0.214 & 0.010 \\
\hline & $M$ & 242 & 205,279 & 206 & 150,262 & & \\
\hline \multirow[t]{2}{*}{ Phosphorus (mg) } & $\mathrm{F}$ & 368 & 337,399 & 380 & 316,444 & 0.042 & 0.472 \\
\hline & $M$ & 421 & 390,451 & 338 & 292,385 & & \\
\hline \multirow[t]{2}{*}{ Zinc (mg) } & $\mathrm{F}$ & $4 \cdot 2$ & $3 \cdot 9,4 \cdot 6$ & $4 \cdot 2$ & $3.5,4.9$ & 0.067 & 0.017 \\
\hline & $M$ & $5 \cdot 2$ & $4 \cdot 8,5 \cdot 5$ & $4 \cdot 2$ & $3 \cdot 7,4 \cdot 7$ & & \\
\hline \multirow[t]{2}{*}{ Iron (mg) } & $\mathrm{F}$ & 5.4 & $4 \cdot 7,6 \cdot 1$ & 5.4 & $3 \cdot 9,6 \cdot 8$ & 0.581 & 0.279 \\
\hline & $M$ & 6.4 & $5 \cdot 7,7 \cdot 1$ & $5 \cdot 7$ & $4 \cdot 6,6 \cdot 8$ & & \\
\hline
\end{tabular}

${ }^{a}$ The significance indicated is that of the interaction term, sex $\times$ stunting.

${ }^{\mathrm{b}}$ Each of the seven ANCOVA models was evaluated at age 112.4 months. In four of the seven cases the covariate age term is significant. 
Table 6. Analysis of covariance (ANCOVA) of some growth-limiting biochemical indices of micronutrient status as the dependent variable with sex and stunting treated as categorical variables and age as a covariate

\begin{tabular}{|c|c|c|c|c|c|c|c|c|}
\hline \multirow[b]{2}{*}{ Dependent variable } & \multirow[b]{2}{*}{ Sex } & \multicolumn{3}{|c|}{ Non-stunted } & \multicolumn{3}{|c|}{ Stunted } & \multirow[b]{2}{*}{$P^{*}$} \\
\hline & & Mean & $95 \% \mathrm{Cl}$ & $n$ & Mean & $95 \% \mathrm{Cl}$ & $n$ & \\
\hline \multirow{2}{*}{$\begin{array}{l}\text { Serum } \\
\quad \text { ferritin† }(\mu \mathrm{g} / \mathrm{l})\end{array}$} & $\mathrm{F}$ & $37 \cdot 7$ & $31 \cdot 8,45 \cdot 2$ & 92 & & & & \multirow[t]{2}{*}{ Sex NS; stunting NS, sex $\times$ stunting NS, age $<0.001$} \\
\hline & M & $38 \cdot 1$ & $33 \cdot 1,43 \cdot 8$ & 113 & & & & \\
\hline \multirow{2}{*}{$\begin{array}{l}\text { Serum transferrin } \\
\text { receptor }(\mathrm{mg} / \mathrm{l})\end{array}$} & $\mathrm{F}$ & 6.94 & $6 \cdot 37,7 \cdot 51$ & 97 & & & & \multirow[t]{2}{*}{ Sex NS; stunting NS, sex $\times$ stunting NS, age $<0.001$} \\
\hline & $M$ & $6 \cdot 72$ & $6 \cdot 27,7 \cdot 18$ & 120 & & & & \\
\hline \multirow{2}{*}{$\begin{array}{l}\text { Serum } \\
\quad \text { retinol }(\mu \mathrm{mol} / \mathrm{l})\end{array}$} & $\mathrm{F}$ & 1.34 & $1.25,1.42$ & 97 & & & & \multirow[t]{2}{*}{ Sex NS; stunting NS, sex $\times$ stunting NS, age $<0.001$} \\
\hline & M & $1 \cdot 25$ & $1 \cdot 19,1 \cdot 32$ & 122 & & & & \\
\hline \multirow{2}{*}{$\begin{array}{l}\text { Serum albumin } \\
(\mathrm{g} / \mathrm{l})\end{array}$} & $\mathrm{F}$ & 47.5 & $46 \cdot 5,48 \cdot 4$ & 92 & & & & \multirow[t]{2}{*}{ Sex $=0.008$; stunting NS, sex $\times$ stunting NS, age NS } \\
\hline & $M$ & $45 \cdot 9$ & $45 \cdot 2,46 \cdot 6$ & 118 & & & & \\
\hline \multirow{2}{*}{$\begin{array}{l}\text { Urinary } \\
\quad \text { iodine† }(\mu \mathrm{g} / \mathrm{l})\end{array}$} & $\mathrm{F}$ & $49 \cdot 4$ & $42 \cdot 1,58 \cdot 0$ & 102 & & & & \multirow[t]{2}{*}{ Sex $=0.012$; stunting NS, sex $\times$ stunting NS, age NS } \\
\hline & $M$ & $66 \cdot 7$ & $58 \cdot 0,74 \cdot 4$ & 122 & & & & \\
\hline \multirow{2}{*}{$\begin{array}{l}\text { Serum zinc } \\
(\mu \mathrm{mol} / \mathrm{l})\end{array}$} & $\mathrm{F}$ & $9 \cdot 64$ & $9 \cdot 23,10 \cdot 06$ & 71 & $10 \cdot 58$ & $9.67,11.49$ & 15 & \multirow[t]{2}{*}{ Sex $\times$ stunting $=0.026$, age NS } \\
\hline & M & $9 \cdot 70$ & $9 \cdot 29,8 \cdot 53$ & 75 & $9 \cdot 19$ & $8.53,9.84$ & 29 & \\
\hline
\end{tabular}

* Each of the six ANCOVA models was evaluated at approximately age 112 months, the exact age depending on the sample. In five of the six cases the interaction term sex $\times$ stunting is non-significant and there are no significant biochemical difference between the stunted and non-stunted children. Only in the case of serum zinc is the interaction term sex $\times$ stunting significant.

†Data for serum ferritin and urinary iodine based on log-transformed values.

a concomitant decrease in food intake, and thus deficits in energy and associated nutrients. An alternative hypothesis is to view the non-stunted male children as representing boys who are taller, with more muscle, larger appetites, and therefore higher food intakes. We prefer to view these non-stunted male children as 'normal', but their much higher energy and nutrient intakes are certainly a striking feature of the data presented in Table 5.

The present dietary data also confirm that the low biochemical zinc status of the stunted male children was associated with low intakes of zinc per se (Table 5), and not with low intakes of absorbable zinc arising from the inhibitory effect of phytate on zinc absorption (Lönnerdal, 2000). Such low intakes of zinc arise in part because the diets of the children were based on glutinous rice (Oryza glutinosa) grown on the low-zinc soils of NE Thailand (Umar Khan et al. 2002; Alloway, 2004). Glutinous rice also has a low content of phytate, even when raw (Krittiphol et al. in press), that is further reduced by washing and soaking overnight in water prior to cooking. Both of these practices leach water-soluble potassium and magnesium phytates into the water, which is then discarded (Perlas \& Gibson, 2002). Therefore, it is not surprising that, unlike the unrefined maizebased diets of school children in many Sub-Saharan African countries (Gibson, 1993; Murphy et al. 1995; Yeudall et al. 2005), the phytate intakes of all the NE Thai school children of the present study were very low (Table 3 ).

The lower protein intakes observed in the male stunted children of the present study were not associated with correspondingly lower serum albumin concentrations; no significant interaction existed between sex and stunting for serum albumin (Table 6). This suggests that protein status was probably not associated with stunting among these male children at the time of the study. Certainly, both stunted and non-stunted children (Table 2) had higher mean plasma albumen concentrations than non-stunted, healthy middle-class Nepali children of a comparable age (Panter-Brick et al. 2001). Allen (1994) noted that linear growth faltering, or subsequent failure to 'catch up', can occur in the presence of adequate intakes of energy and/or protein. In addition, protein intakes reported in this study probably met the FAO/WHO/UNU requirements (Food \& Agriculture
Organization/World Health Organization/United Nations University, 1985), even when a $50 \%$ increment in the growth component of the requirement is applied to allow for catch-up growth for the stunted children, and the protein intake is not adjusted for amino acid composition. Limited data are available on the amino acid composition of Thai foods. However, protein utilization is unlikely to be compromised by poor digestibility because the dietary fibre content of these NE Thai diets was very low (Table 3).

Unlike protein, no biochemical indices of phosphorus status were measured in the present study. Hence, whether the lower phosphorus intake in the male stunted children (Table 5) was associated with a compromised biochemical phosphorus status is unknown. Low phosphorus intakes among NE Thai children consuming diets based on glutinous rice have been reported by others (Valyasevi et al. 1969; Chusilp et al. 1992). Indeed, Chusilp et al. (1992) in a study of NE Thai pre-school children reported very low phosphorus intakes among those in the lowest tercile for length attained at 2 years, but whether the poor linear growth was sex-related was not reported.

The mean calcium intake of the male stunted children was lower than the intake of the non-stunted males. Indeed, the mean calcium intakes of all four groups of children studied were very low and below those reported for NE Thai preschool children in the Thai National Nutrition Survey (Ministry of Public Health, 1995). Children consuming plant-based diets characteristically have such low calcium intakes (Murphy et al. 1995), but these have not been associated with linear growth failure. Indeed, there is some evidence that populations in Asia may have increased calcium retention and thus adequate bone mineralization at lower intakes of calcium (Food \& Agriculture Organization/World Health Organization, 2002).

In the present study, the mean dietary zinc intake of these stunted NE Thai male children was very low compared to that of their non-stunted counterparts (Table 5). Furthermore, the stunted males also had a lower intake of animal protein (Table 5), although the interaction term sex $\times$ stunting was not significant. Animal protein is a rich source of readily available zinc (Lönnerdal, 2000). Several studies have observed 
significant and positive correlations between intakes of animal protein and attained height, even after controlling for sociodemographic variables (Allen et al. 1991, 1992; Paik et al. 1992).

Earlier research suggests that deficits in stature among children in NE Thailand commence within the first 3 months of life and increase steadily up to about the second (Chusilp et al. 1992) or third year of life (Ministry of Public Health, 1995), remaining relatively constant thereafter. This trend is consistent with that noted in many other developing countries (Rivera \& Ruel, 1997). Moreover, there was a tendency for the deficits in stature to be greater among NE Thai boys than girls, based on the most recent Thai National Nutrition Survey (Ministry of Public Health, 1995). Hence, linear growth failure for the NE Thai children in the present study probably began during early childhood, a time when the adverse effects of poor dietary intakes and frequent infections on growth play a crucial role (World Health Organization, 1998). We recognize that the present 24-h recall data only provide information on recent dietary intakes and not on intakes at the likely onset of linear growth failure in these children (i.e. during the first 3 years of life). However, in this region rice and rice products provide the major proportion of the dietary energy throughout childhood (Ministry of Public Health, 1995; Winichagoon, 2002), so it is likely that the food consumption patterns of these NE Thai children were probably comparable during their earlier childhood. Whether zinc was the crucial limiting micronutrient in relation to dietary adequacy and stunting among the male children of this study during these earlier phases of growth is unknown.

Genetic differences are unlikely to be responsible for stunting among these primary school children in NE Thailand because there is no evidence that growth potential among population groups in Thailand is influenced by genetic differences (Chusilp et al. 1992). Indeed, there is little difference between the growth curves for healthy Thai children during the first 5 years of life (Ministry of Public Health, 1987) and those of US children of similar age, compiled by the NCHS (Hamill et al. 1979). Likewise, ethnic differences were not a factor because all the participating children were of Thai ethnicity. Several investigators have provided convincing evidence that genetic and ethnic differences are less important in linear growth during childhood than the influences of food intake, dietary quality and morbidity (Martorell et al. 1994; Mei et al. 1998).

The stunted children of the present study were underweight and thinner than their non-stunted counterparts, as indicated by significantly lower mean weight-for-height Z-scores (WHZ) and BMI, respectively (Table 2).

Even the non-stunted children of this study had a mean energy intake well below the FAO/WHO/UNU average requirement for light physical activity (Food \& Agriculture Organization/World Health Organization/United Nations University, 2004). The low WHZ and BMI were accompanied by significantly lower anthropometric indices of body fat and muscle mass in the stunted children compared to their nonstunted counterparts (Table 2).

Low WHZ and BMI have also been noted among stunted school children in some countries including Nepal and Zanzibar (Stoltzfus, 2001), although in most Latin American countries, the WHZ and BMI of stunted children are generally not low (Post \& Victora, 2001). Reasons for the differences that distinguish the stunted, thinner Thai children from their stunted but fatter Latin American counterparts are unclear. Post and Victora (2001) have argued that differences in body proportions may account for the apparently adequate WHZ among stunted Latin American children.

In summary, the present results suggest that zinc may have a crucial role in stunting in these children from NE Thailand. Support for this suggestion stems from the greater prevalence of stunting among the males, coupled with their lower serum zinc concentrations, and lower intakes of zinc, as well as energy and other growth-limiting nutrients compared to their nonstunted male counterparts. This conclusion is further supported by the significant improvement in serum zinc concentrations observed among some of these NE Thai school children after they consumed a school lunch containing a seasoning powder fortified with micronutrients, including zinc, for 31 weeks compared to their counterparts consuming an unfortified lunch. Nevertheless, further research is required to identify all the nutritional and health factors responsible for limiting the linear growth of these NE Thai children. Sustainable interventions are needed that permit full catch-up growth during childhood so that the adverse effects associated with stunting in both school-age years and adulthood can be avoided.

\section{Acknowledgements}

We thank the school teachers and the children and their families who participated in this study, and the dedicated research assistants. We also thank Ian L. Gibson for his support during and after the project. This project was supported by the Micronutrient Initiative Fund and the University of Otago Research Fund.

\section{References}

Adair LS \& Guilkey DK (1997) Age-specific determinants of stunting in Filipino children. $J$ Nutr 127, 314-320.

Aggett PJ (1995) Zinc and human health. Nutr Rev 53, S16-S22.

Allen LH (1994) Nutritional influences on linear growth: a general review. Eur J Clin Nutr 48, S75-S89.

Allen LH, Backstrand JR, Stanek EJ III, Pelto G, Chávez A, Molina E, Beatriz Castillo J \& Mata A (1992) The interactive effects of dietary quality on the growth and attained size of young Mexican children. Am J Clin Nutr 56, 353-364.

Allen LH, Black AK, Backstrand JR, Pelto GH, Ely RD, Molino E \& Chávez A (1991) An analytical approach for exploring the importance of dietary quality versus quantity in the growth of Mexican children. Food Nutr Bull 13, 95-104.

Alloway BJ (2004) Zinc in Soils and Crop Nutrition. Brussels, Belgium: International Zinc Association.

Banjong O, Viriyapanich T \& Chittchang U (2001) Food Quantity Conversion Handbook. Salaya, Thailand: Community Nutrition, Institute of Nutrition, Mahidol University.

Bloem MW, Wedel M, Egger RJ, Speek AJ, Chusilp K, Saowakontha S \& Schreurs WH (1989) A prevalence study of vitamin A deficiency and xerophthalmia in northeastern Thailand. Am J Epidemiol 129, 1095-1103.

Brown KH, Peerson JM, Rivera J \& Allen LH (2002) Effect of supplemental zinc on the growth and serum zinc concentrations of prepubertal children: a meta-analysis of randomized controlled trials. Am J Clin Nutr 75, 1062-1071.

Bunch S \& Murphy SP (1994) User's Guide to the Operation of the World Food Dietary Assessment Program. Berkeley, CA: Office of Technology Licensing, University of California. 
Buzina R, Jusic M, Sapunar J \& Milanovic N (1983) Zinc nutrition and taste acuity in school children with impaired growth. Am $J$ Clin Nutr 33, 2262-2267.

Castillo-Duran C, Garcia H, Venegas P, Torrealba I, Panteon E, Concha N \& Perez P (1994) Zinc supplementation increases growth velocity of male children and adolescents with short stature. Acta Paediatr 83, 833-837.

Cavan KR, Gibson RS, Grazioso CF, Isalgue AM, Ruz M \& Solomons NW (1993) Growth and body composition of periurban Guatemalan children in relation to zinc status: a cross-sectional study. Am J Clin Nutr 57, 334-343.

Chusilp K, Somnasang P, Kirdpon W, Wongkham S, Sribonlue P, Mahaverawat U, Yongvanit P, Sawakontha S \& Waterlow J (1992) Observation on the development of stunting in children of the Khon Kean region of Thailand. Eur J Clin Nutr 46, 475-488.

Egger RJ, Hofhuis EH, Sukonthanyakorn B, Van der Ven EM, Scriboonlue P, Wedel M, Saowakon S \& Scheurs WH (1991) Food intake and socioeconomic status in children in northeast Thailand. Trop Geogr Med 43, 42-50.

Ferguson EL, Gadowsky S, Huddle J-M, Cullinan T, Lehrfeld J \& Gibson RS (1995) An interactive 24-h recall technique for assessing the adequacy of trace mineral intakes of rural Malawian women: its advantages and limitations. Eur J Clin Nutr 49, 565-578.

Ferguson EL, Gibson RS, Ounpuu S \& Sabry J (1989) The validity of the 24 hour recall for estimating the energy and selected nutrient intakes of a group of rural Malawian preschool children. Ecol Food Nutr 23, 273-285.

Food and Agriculture Organization/World Health Organization (2002) Human Vitamin and Mineral Requirements. Rome: Food and Nutrition Division, FAO/WHO.

Food and Agriculture Organization/World Health Organization/ United Nations University (1985) Energy and Protein Requirements. WHO Technical Report Series no. 274. Geneva: WHO.

Food and Agriculture Organization/World Health Organization/ United Nations University (2004) Human Energy Requirements. Food and Nutrition Technical Report Series no. 1. Rome: FAO/ WHO/UNU.

Gibson RS (1993) Zinc nutrition in developing countries. Nutr Res Rev 10, $1-18$.

Gibson RS (2005) Principles of Nutritional Assessment. New York: Oxford University Press.

Gibson RS \& Ferguson EL (1999) An Interactive 24-hr Recall for Assessing the Adequacy of Iron and Zinc Intakes in Developing Countries. Washington, DC: International Life Sciences Institute Publishers.

Gibson RS, Heywood A, Yaman C, Sohström A, Thompson LU \& Heywood P (1991) Growth in children from the Wosera subdistrict, Papua New Guinea, in relation to energy and protein intakes and zinc status. Am J Clin Nutr 53, 782-789.

Gibson RS, Smit-Vanderkooy PD, MacDonald AC, Goldman A, Ryan BA \& Berry M (1989) Growth limiting mild zinc deficiency syndrome in some Southern Ontario boys with low height percentiles. Am J Clin Nutr 49, 1266-1273.

Gopalan C (1988) Stunting: significance and implications for public health policy. In Linear Growth Retardation in Less Developed Countries, pp. 265-284 [JC Waterlow, editor]. Nestle Nutrition Workshop Series, vol. 14, Nestec Ltd. New York: Vevey/Raven Press, Ltd.

Hambidge KM (2000) Human zinc deficiency. J Nutr 130, 1344S-1349S.

Hambidge KM, Hambidge C, Jacobs M \& Baum JD (1972) Low levels of zinc in hair, anorexia, poor growth, and hypogeusia in children. Pediatr Res 6, 868-874.

Hambidge KM, Krebs NF \& Walravens PA (1985) Growth velocity of young children receiving a dietary zinc supplement. Nutr Res 1, 306-316.
Hamill PVV, Drizd TA, Johnson CL, Reed RB, Roche AF \& Moore WM (1979) Physical growth: National Center for Health Statistics percentiles. Am J Clin Nutr 32, 607-629.

Hotz C \& Brown KM (2004) Assessment of the risk of deficiency in populations and options for its control. Food Nutr Bull 25, S99-S199.

Hulley SB \& Cummings SR, (editors) (1988) Designing Clinical Research: An Epidemiological Approach. Baltimore, MD: Lippincott Williams \& Wilkins.

Institute of Nutrition, Mahidol University (2002) Food Composition Database for INMUCAL Program. Thailand: Institute of Nutrition, Mahidol University.

Kramer TR, Udomkesmalee E, Dhanamitta S, Sirisinha S, Charoenkiatkul S, Tuntipopipat S, Banjong O, Rojroongwasinkul N \& Smith JC Jr (1993) Lymphocyte responsiveness of children supplemented with vitamin A and zinc. Am J Clin Nutr 58, $566-570$.

Krittaphol W, Bailey KB, Pongcharoen T, Winichagoon P \& Gibson RS (in press) Low zinc, iron, and calcium intakes of Northeast Thai school children consuming glutinous rice-based diets are not exacerbated by high phytate. Int J Food Sci Nutr.

Krebs NF, Hambidge KM \& Walravens PA (1984) Increased food intake of young children receiving a zinc supplement. Am J Dis Child 138, 270-273.

Lönnerdal B (2000) Dietary factors influencing zinc absorption. J Nutr 130, 1378S-1383S.

Martorell R, Kettel Khan L \& Schroeder D (1994) Reversibility of stunting: epidemiological findings in children from developing countries. Eur J Clin Nutr 48, S45-S57.

Mei Z, Yip R \& Trowbridge F (1998) Improving trend of growth of Asian refugee children in the USA: evidence to support the importance of environmental factors on growth. Asia Pacific J Clin Nutr 7, 111-116.

Ministry of Public Health (1987) Standard Weight, Height, and Nutrition Status Indicators for Thai Population of Ages 1 day-19 years. Working Group for Formulation of Standard Weight, Height, and Nutrition Indicators of Thai Population. Department of Health.

Ministry of Public Health (1989) Recommended Daily Dietary Allowances for Healthy Thais. Bangkok: The Committee on Recommended Daily Dietary Allowances, Department of Health.

Ministry of Public Health (1995) The Fourth National Nutrition Survey of Thailand. Thailand: Department of Health, Ministry of Public Health.

Murphy SP, Calloway DH \& Beaton GH (1995) Schoolchildren have similar predicted prevalences of inadequate intakes as toddlers in village populations in Egypt, Kenya, and Mexico. Eur J Clin Nutr 49, 647-657.

Paik HY, Hwang SH \& Lee SP (1992) Comparative analysis of growth, diet, and urinary $\mathrm{N}$ excretion in elementary school children from urban and rural areas of Korea. Int J Vitam Nutr Res 62, 83-90.

Panter-Brick C, Lunn PG, Baker R \& Todd A (2001) Elevated acutephase protein in stunted Nepali children reporting low morbidity: different rural and urban profiles. Brit J Nutr 85, 125-131.

Parnell W, Scragg R, Wilson N, Schaaf D \& Fitzgerald E (2003) NZ Food, NZ Children; Key Results of the 2002 National Children's Nutrition Survey. Wellington: Ministry of Health.

Pelto GH, Urgello J, Allen LH, Chavez A, Martinez H, Meneses L, Capacchione C \& Backstrand J (1991) Household size, food intake and anthropometric status of school-age children in a highland Mexican area. Soc Sci Med 33, 1135-1140.

Perlas L \& Gibson RS (2002) Use of soaking to enhance the bioavailability of iron and zinc from rice-based complementary foods used in the Philippines. J Sci Food Agric 82, 1115-1124.

Post CL \& Victora CG (2001) The low prevalence of weight-forheight deficits in Brazilian children is related to body proportions. J Nutr 13, 1290-1296.

Puwastien P, Burlingame B, Raroengwichit M \& Sungpuang P (2000) ASEAN Food Composition Tables. Salaya: Institute of Nutrition, Mahidol University. 
Rivera J \& Ruel MT (1997) Growth retardation starts in the first three months of life among rural Guatemalan children. Eur J Clin Nutr 51, 92-96.

Ruz M, Castillon-Duran C, Lara X, Codoceo J, Rebolledo A \& Atalah E (1997) A 24-mo zinc-supplementation trial in apparently healthy Chilean preschool children. Am J Clin Nutr 66, 1406-1413.

Sandstead HH, Penland JG, Alcok NW, Dayal HH, Chen XC, Li JS, Zhao F \& Yang JJ (1998) Effects of repletion with zinc and other micronutrients on neuropsychologic performance and growth of Chinese children. Am J Clin Nutr 68, 470S-475S.

Siong TE, Noor MI, Adudin MN \& Idris K (1997) Nutrient Composition of Malaysia Foods, 4th ed. Kuala Lumpur: Institute for Medical Research.

Smit-Vanderkooy P \& Gibson RS (1987) Food consumption patterns of Canadian pre-school children in relation to zinc and growth status. Am J Clin Nutr 42, 165-169.

Soemantri AG, Pollitt E \& Kin I (1985) Iron deficiency anemia and educational achievement. Am J Clin Nutr 42, 1221-1228.

Spurr G (1988) Body size, physical work capacity and productivity in hard work: is bigger better? In Linear Growth Retardation in Less Developed Countries, pp. 215-243 [J Waterlow, editor]. New York: Vevey/Raven Press.

Stoltzfus RJ (2001) Growth of school-age children. In Nutrition and Growth, pp. 257-280 [R Martorell and F Haschke, editors]. Nestlé Nutrition Workshop Series, Pediatric Program, vol. 47, Nestec Ltd. Philadelphia: Vevey/Lippincott Williams \& Wilkins.

Thurlow RA, Winichagoon P, Green T, Wasantwisut E, Bailey KB \& Gibson RS (2005) Only a small proportion of anemia in North East Thai children is associated with iron deficiency. Am J Clin Nutr 82, 380-387.

Thurlow RA, Winichagoon P, Pongcharoen T, Gowachirapant S, Boonpraderm A, Manger MS, Bailey KB, Wasantwisut E \& Gibson RS (2006) Risk of zinc, iodine, and other micronutrient deficiencies among school children in N.E. Thailand. Eur J Clin Nutr 60, 623-632.

Udomkesmalee E, Dhanamitta S, Sirisinha S, Charoenkiatkul S, Tuntipopipat S, Banjong O, Rojroongwasinkul N, Kramer TR \& Smith JC Jr (1992) Effect of vitamin A and zinc supplementation on the nutriture of children in Northeast Thailand. Am J Clin Nutr 56, 50-57.

Umar Khan M, Qasim M \& Jamil M (2002) Effect of different levels of zinc on the extractable zinc content of soil and chemical composition of rice. Asian J Plant Sci 1, 20-21.
Umeta M, West CE, Haidar J, Deurenberg P \& Hauvast JGAJ (2002) Zinc supplementation and stunted infants in Ethiopia: a randomized controlled trial. Lancet 355, 2021-2026.

United States Department of Agriculture (2003) USDA National Nutrient Database for Standard Reference, Release 16. Nutrient Data Laboratory. http://www.nal.usda.gov/finc/foodcomp.

Valyasevi D, Dhanamitta S \& Van Rees R (1969) Effect of orthophosphate and non-fat dry milk supplementation on urine composition. Am J Clin Nutr 22, 218-227.

Van Stuijvenberg ME, Kvasvig JD, Faber M, Kruger M, Kenoyer DG \& Benade AJ (1999) Effect of iron-, iodine-, and beta-carotene-fortified biscuits on the micronutrient status of primary school children: a randomized controlled trial. Am J Clin Nutr 69, 497-503.

Walravens PA \& Hambidge KM (1976) Growth of infants fed a zinc supplemented formula. Am J Clin Nutr 26, 1114-1120.

Walravens PA, Krebs NF \& Hambidge KM (1983) Linear growth of low income preschool children receiving a zinc supplement. Am J Clin Nutr 38, 195-201.

Welch RM \& Graham RD (2004) Breeding for micronutrients in staple food crops from a human nutrition perspective. J Exp Bot 55, 353-364.

Winichagoon P (2002) Prevention and control of anemia: Thailand experiences. J Nutr 132, 862S-866S.

Winichagoon P, McKenzie J, Chavasit V, et al. (2006) Randomized controlled trial of the efficacy of a seasoning powder fortified with iron, zinc, iodine, and vitamin A on the micronutrient status of primary school children in North East Thailand. J Nutr 36, $1617-1623$.

World Health Organization (1986) Use and interpretation of anthropometric indicators of nutritional status. Bull World Health Org 64, 929-941.

World Health Organization (1995) Physical Status: The Use and Interpretation of Anthropometry. WHO Technical Report Series no. 854. Geneva: WHO.

World Health Organization (1998) Complementary Feeding in Developing Countries: A Review of Current Knowledge. Geneva: WHO.

Yeudall F, Gibson RS, Cullinan TR \& Mtimuni B (2005) Efficacy of a community-based dietary intervention to enhance micronutrient adequacy of high-phytate maize-based diets of rural Malawian children. Pub Health Nutr 8, 826-836. 